stem borers, the assessinent of losses caused by them and with methods for their control. Most readers will find the thirteen papers on the varied aspects of controlchemical, cultural, biological, integrated and produced by plant breeding - the most valuable part of this book. These papers are well presented and contain a large proportion of original work. They are followed by a short session which deals with taxonomy, distribution, host range, life cycles and control of rice gall midges, rice leaf hoppers and rice bugs.

The eighth session attempts to give in 136 pages a survey of the present status of work on major rice insects in the United States, Thailand, Ceylon, the Philippines, Malaysia, East Pakistan, Korea and Indonesia. Many of these reports give very useful accounts of pests which cause serious losses in the areas concerned, and the methods being used to control them. There are comparisons between insecticides, and original experimental results, which will be very interesting for workers dealing with similar situations.

This book also contains the reports of five special committees for the symposium, on such topics as common nomenclature of stem borers, suggestions for standard plot size and sampling units, procedure in making croploss estimates, improving communication among entomologists, and hazards involved in the use of insecticides.

Considered as a whole the publication will be of value to specialists in rice entomology. By its efforts to coordinate work which is in progress throughout the rice-growing areas of the world it will give many workers a great deal of basic information on the problems they are likely to encounter when setting up research programmes.

Susan D. Feakin

\section{PROTEIN TECHNIQUES}

Symposium on Modern Methods in the Investigation of Protein Structure

Edited by F. B. Straub. Assisted by P. Friedrich. Pp. 93. (Budapest: Akademiai Kiado, 1967.) $42 s$.

THese are the proceedings of a small symposium held at, Budapest in 1965 on modern techniques in protein structure determination. The papers, with one exception, are reviews of the achievements of a particular technique. Some theoretical background is given, but very little. The exception is a short paper by Mejbaum-Katzonellen. bogen on the use of tannin in determining protein concentration. This is a turbidimetric method developed by the author and the paper seoms rather out of place in this collection.

The other five papers deal with sequence analysis by enzyme digestion, structural studies by diffraction methods, optical rotatory dispersion, chemical modification of side chains and studies on the structure of the active site of enzymes. These reviews are not very extensive and suffer from a rather sketchy bibliography; in one case a paper is identified merely as by "a group of Italian workers in 1965".

There must be many such short meetings every year. They may be interesting and informative to the participants, but so little is presented that is not already available in much better form, that their publication can scarcely be justified.

I. G. JONES

\section{CHROMATOGRAPHY JOURNAL}

\section{Chromatographia}

Friedr. Vieweg and Sohn: Pergamon Press. Bi-monthly. Annual subscription £11 $12 s$.

THE reviewer of a new journal has not a completed work before him as has the reviewer of a book. Generally, as in this instance, he must base his judgement on the stated aims of the editors and on the first number. The first number may not be typical; past experience shows that editors usually manage to collect better and more articles for the early numbers than for those printed after a year or so, although the standard may rise again when the journal is well-established.

The editors of Chromatographia, from the United Kingdom, France, Germany and Hungary, aim to publish articles on all branches of chromatography and related techniques under the following headings. Original papers written in English, French or German with title, summary and captions in all three languages; short communications with titles in three languages and an English summary if the text is French or (xerman; letters to the editors; review articles with titles and summaries in three languages; green pages written in English, French and German giving details of laboratory practice; scientific articles by instrument manufacturers; general information on conferences and so on given in throe languages. The multiplicity of languages is intended to "depass linguistic boundaries" (the error is not a good omen). It is claimed that publication will be far more rapid than in "traditionally" produced journals though no explanation as to how this will be compatible with a proper system of refereeing is given.

The general intentions are innocuous. Strong objection may, however, be taken to the publication by instrument manufacturers of puff for their products in an expensive journal. They normally distribute such advertising material (like the very good Aerograph notes) free.

Several journals have attempted multilingual summaries in the past and have generally abandoned them along with other linguistic gimmicks. They are a great nuisance for editors and of doubtful value for readers. To judge by this number they add greatly to the cost of production. When proper allowance is made for linguistic proliferation it is found that there are only fifty pages of text. Presumably a year's subscription will provide 300 similar pages, that is $£ 1$ for twenty-six pages for a library. The United Kingdom subscriber to Analytical Chemistry, which carries similar material, bought 248 larger pages of scientific papers for $£ l$ in 1967 . In the United States $\$ 2.40$ bought 610 pages. The comparison is fair as both journals carry advertisements. It is to be hoped that the scientific community will give no support to such a bad bargain as Chromatographia, on the available evidence, appears to be.

A. F. Trotman-Dickenson

\section{MORE CHROMATOGRAPHY}

\section{Thin-Layer Chromatography}

(Techniques of Organic Chemistry, Vol. 12.) By Justus G. Kirchner. Pp. xxi +788 . (New York and London: Interscience Publishers, a Division of John Wiley and Sons, 1967.) 176s.

DUring the past twelve years there have been many developments in thin-layer chromatography (TLC) and it is now well established as one of the most useful methods for separating small quantities of mixtures into their components. It can be applied to volatile and non-volatile substances and to hydrophilic and hydrophobic substances both for qualitative and quantitative analysis. F'or analytical purposes the microgram or even nanogram range is used, while for preparative TLC up to $0.5 \mathrm{~g}$ of mixture may be separated and the individual components isolated as chromatographically pure substances. As was to be expected, this new technique led to a number of useful books, which in terms of its application to various problems are now becoming dated. This book, by Justus Kirchner, one of the earliest exponents of TLC, is the first in the new round of books published in Fnglish. The first part deals with the technique itself and the second 